\title{
Optimization test of ipomoea batatas l. leaf extract as a flocculent in water treatment for practicum in chemical analysis of environment course
}

\author{
Hana Rohana ${ }^{1}$, Cahyo Puji Asmoro \\ \{hanarohana1970@gmail.com ${ }^{1}$ \} \\ Environmental Chemistry Research Laboratory, Universitas Pendidikan Indonesia ${ }^{1}$, Earth and Space \\ Laboratory, Universitas Pendidikan Indonesia ${ }^{2}$
}

\begin{abstract}
This research is a continuation of the previous research on optimizing Ipomoea batatas L. leaf extract as a flocculent in water treatment for practicum on the chemistry of environmental analysis. This study will be carried out through two stages, the first step is to optimize the optimal processing parameters. Secondly it is water treatment using optimal processing parameters, followed by testing hardness in the water sample before and after processing for hardness testing using the EDTA titration method with the EBT indicator. The results showed the optimal parameters of water treatment with Ipomoea batatas L leaf extract as flocculent was $\mathrm{pH} 7.17$, coagulant dose $8 \mathrm{~mL}$, flocculent dose $3 \mathrm{~mL}$, stirring coagulant speed $200 \mathrm{rpm}$ for 7.5 minutes, and flocculent stirring speed $30 \mathrm{rpm}$ for 10 minutes. The results indicate Ipomoea batatas L. leaf extract as a flocculent in water treatment can also reduce the total hardness level in the water.
\end{abstract}

Keywords: : Bio-flocculant, Ipomoea Batatas L., EDTA Titration, Hardness

\section{Introduction}

The environmental chemistry research laboratory in the chemical education department at Universitas Pendidikan Indonesia has practicum activities in water treatment. Through this practicum, students are expected to have procedural and analytical skills related to water treatment, as we know that water is the main need of humanity. Based on the provisions in Government Regulation Number 66 of 2014, water is one of the environmental media which must be set by the Environmental Health Standard Quality Standards and Health Requirements.

Environmental Health Standard Quality Standards for Water media include physical, biological, and chemical parameters which can be mandatory and additional parameters. This research will focus on chemical parameters, namely hardness. Hardness is a term used in water containing high amounts of cations. Generally, hardness is caused by the presence of metals or validated cations, such as $\mathrm{Fe}, \mathrm{Sr}, \mathrm{Mn}, \mathrm{Ca}$ and $\mathrm{Mg}$, but the main causes of hardness are calcium (Ca) and magnesium $(\mathrm{Mg})$. Calcium in water has the possibility of compounding with bicarbonate, sulfate, chloride, and nitrate, while magnesium contained in water may be compounded with bicarbonate, sulfate and chloride [1].

Water that is too high in hardness can cause scale buildup in household appliances and is known to reduce soap efficiency [2,3,4]. As for the human body, high hardness water can cause various diseases such as diarrhea [5], blockage of heart vessels and kidney stones [6]. Therefore research needs to be done to find a formula to reduce hardness, while the hardness of water in 
accordance with WHO recommendations is that water containing up to $60 \mathrm{mg} / \mathrm{L}$ is defined as soft water, $60-120 \mathrm{mg} / \mathrm{L}$ is water that is hard enough, $120-180 \mathrm{mg} / \mathrm{L}$ is hard water, and 180 $\mathrm{mg} / \mathrm{L}$ and above is called very hard water [7].

In general, water treatment consists of 3 aspects, namely physical, chemical and biological treatment. In physical processing, it is usually done mechanically, without the addition of chemicals. Examples are deposition, filtration, adsorption, and others. In chemical processing, there is the addition of chemicals, such as chlorine, alum, etc., this material is usually used to remove heavy metals contained in water. Whereas in biological processing, microorganisms are usually utilized as a processing medium. Chemical water treatment processes consist of coagulation, flocculation, and deposition processes.

Previous studies have examined the ability of Ipomoea batatas L. leaf extract as a substitute for polyelectrolyte flocculants derived from synthetic flocculants using the "Jar Test" method obtained by decreasing the value of water turbidity from 251 NTU to 10.8 NTU with an optimum parameter $\mathrm{pH}$ of 6.5 , coagulant dose $25 \mathrm{ppm}$, coagulant stirring speed $250 \mathrm{rpm}$, coagulant stirring time 7.5 minutes, flocculant dose $25 \mathrm{ppm}$, flocculant stirring speed $50 \mathrm{rpm}$, flocculant stirring time 5 minutes [8].

Ipomoea batatas L.(Figure 1) is known as sweet potato. In the taxonomy of plants, sweet potato crop can be classified into Spermatophyte division, class Dicotyledon (dashed two), orders convolvuluses, Convolvulaceae family, genus Ipomoea L., a species of ipomoea batatas L. sweet potato leaf color is dark green and sometimes some leaves with a slightly yellowish color. Chemical content contained in the extract of leaves of ipomoea batatas L. is total phenolics and flavonoids Koncic et al [9]. Flavonoid derivatives contained in leaves of Ipomoea batatas L. in the study of Luo et al [10] showed the presence of tiliroside, astragalin, rhamnositrin, rhamnetin and kaempferol. The leaves of ipomoea batatas L., when extracted with water, produce a solution that is thick and dissolves well in water, this property resembles the nature of polyelectrolytes when dissolved in water.

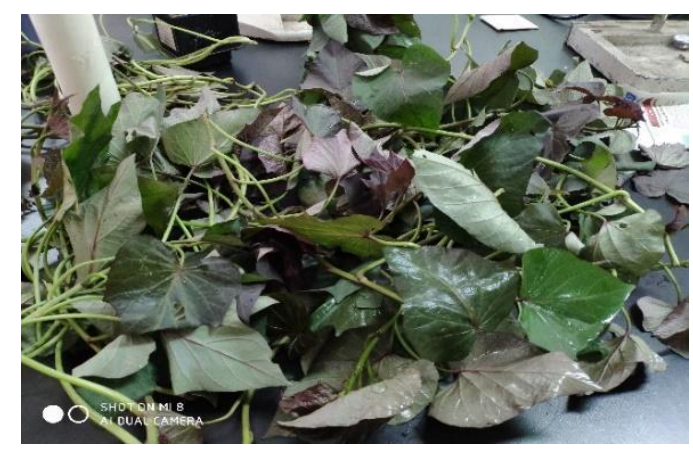

Fig. 1. Ipomoea batatas L. leaves.

In this research, it will be studied how the effect of Ipomoea batatas L. leaf extract on the total hardness contained in water. The sample water used is river water in the Padalarang Cimahi area. The research will be carried out in two stages. The first stage of optimizing the optimum processing parameters is followed by determining the hardness level for each processing parameter. The second stage is water treatment using optimum parameters of treatment, followed by determination of hardness levels in each water sample before and after treatment. In the determination of hardness, the Ethylene Diamine Tetra Acetate (EDTA) titration method is used $[11,12]$ with the Eriochrome Black T (EBT) indicator. Hardness value is defined as total 
hardness and is expressed as $\mathrm{CaCO}_{3}$. From the results of this study can be known the effect of Ipomoea batatas L. leaf extracts on hardness levels contained in water. So that it can be a scientific foundation that the extract of Ipomoea batatas L. leaves can be used or not in water treatment practicum activities as bio-flocculants.

\section{Methods}

In this study, Ipomoea batatas L. leaf extract functions as a bio-flocculant substitute for synthetic flocculants added to the flocculation process. To get the optimum processing parameters, the processing parameter estimation was carried out using the Jar test method by varying the $\mathrm{pH}$, coagulant dose, flocculant dose, coagulant stirring speed, flocculant stirring speed, coagulant stirring time, and flocculant stirring time. The optimum parameter is determined from the measurement of the smallest turbidity value (Figure 2).

Hardness testing is carried out using the complexometric titration method using EDTA. In principle, EDTA salts react with certain metal cations to form soluble chelate complexes. At $\mathrm{pH}$ $10.0 \pm 0.1$, the calcium and magnesium ions in the test sample will react with the EBT indicator, forming a purplish red solution. If Na EDTA is a titrant, calcium and magnesium ions will form complex compounds, the indicator molecules are released again, and at the endpoint of the titration, the solution will change color from purplish red to blue. In this way, you will get total hardness $(\mathrm{Ca}$ and $\mathrm{Mg})$. EDTA as a chelating agent will co-ordinate in coordination with $\mathrm{Ca}^{2+}$ or $\mathrm{Mg}^{2+}$ in water samples by donating lone pairs. EDTA acts as a Lewis base, while $\mathrm{Ca}^{2+}{\text { and } \mathrm{Mg}^{2+}}^{2+}$ ions act as Lewis acids which accept free lone pairs. EDTA is standardized with $\mathrm{CaCl}_{2}$ solution which will also occur complexation reactions with $\mathrm{Ca}^{2+}$ ions from $\mathrm{CaCl}_{2}$ solution. The EBT indicator is added before the titration, so the solution will turn red because EBT binds all $\mathrm{Ca}^{2+}$ and $\mathrm{Mg}^{2+}$ ions to the water sample equation (1).

$$
M^{2+}+E B T \rightarrow \text { complex }\{M-E B T\}(\text { coloured Red })
$$

At the time of the addition of EDTA titration will lead to $\mathrm{Ca}^{2+}$ and $\mathrm{Mg}^{2+}$ separated from the complex with EBT and will bind to EDTA equation (2).

$$
M^{2+}+E D T A \rightarrow \text { complex }\{M-E D T A\}
$$

Due to the release of ions, the color of the solution will turn blue, the EDTA volume indicates the number of ions that cause hardness. 


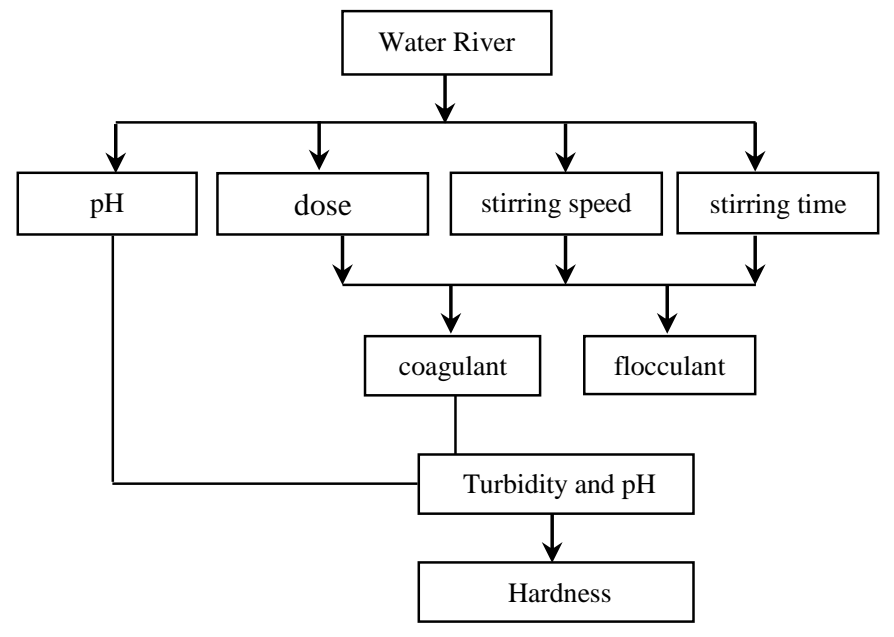

Fig. 2. Research Method.

\section{Results and Discussion}

\subsection{Optimization Stage}

Table 1. shows the initial conditions of untreated water. At each stage of optimization, there was a decrease in the value of turbidity in water. The smallest turbidity value is the optimum value of processing parameters. Decreasing the value of turbidity at each stage of optimization is not followed by a decrease in hardness value. Hardness values tend to remain as in the initial conditions. This can be explained because at the optimization stage, the parameters used for processing are not all optimum. Thus, the coagulation process of flocculation has not yet proceeded perfectly.

Table 1. Initial conditions of the sample.

\begin{tabular}{ccc}
\hline \multirow{3}{*}{$\mathrm{pH}$} & $\begin{array}{c}\text { Conditions before Treatment } \\
\text { Turbidity } \\
(\mathrm{NTU})\end{array}$ & $\begin{array}{c}\mathrm{Ca} \\
(\mathrm{mg} / \mathrm{L})\end{array}$ \\
\hline 7,82 & 70,0 & 310,2 \\
\hline
\end{tabular}

To get the best coagulation results in water treatment, the condition of the wastewater to be treated must have a $\mathrm{pH}$ that matches the coagulant used [13]. If the coagulation process is not carried out in the optimum $\mathrm{pH}$ range, it will result in the failure of the floc formation process and the low quality of the water produced. The effective $\mathrm{pH}$ range for coagulation with alum is at $\mathrm{pH} 5.5$ - 8.0 [14]. Optimization of coagulant and flocculant doses aims to obtain the right dose in the flocculation coagulation process because not all turbidity requires high doses of coagulant and flocculant. Optimization of the stirring speed must be considered in order to obtain fine flocks in the coagulation process and larger flocks in the flocculation process. In the coagulation process, the stirring is carried out at a high speed it is intended that the added 
coagulant can be completely dispersed with water [15]. In contrast to the coagulation process, the stirring flocculation process is carried out slowly so that the formed flocks do not break again. Optimization of stirring time must also be considered so that the flocculation coagulation process takes place efficiently. Table 2 . shows the results of the optimization of processing parameters.

Table 2. Results of optimization of processing parameters.

\begin{tabular}{ccccccc}
\hline & \multicolumn{9}{c}{ Optimum processing parameter conditions } \\
pH & $\begin{array}{c}\text { Coagulant } \\
\text { Dose }\end{array}$ & $\begin{array}{c}\text { Flocculant } \\
\text { Dose }\end{array}$ & $\begin{array}{c}\text { Coagulant } \\
\text { Stirring } \\
\text { Speed }\end{array}$ & $\begin{array}{c}\text { Flocculant } \\
\text { Stirring } \\
\text { Speed }\end{array}$ & $\begin{array}{c}\text { Coagulant } \\
\text { Stirring } \\
\text { Time }\end{array}$ & $\begin{array}{c}\text { Flocculant } \\
\text { Stirring Times }\end{array}$ \\
\hline 7,17 & $8 \mathrm{~mL}$ & $3 \mathrm{~mL}$ & $200 \mathrm{rpm}$ & $30 \mathrm{rpm}$ & $\begin{array}{c}7,5 \\
\text { minutes }\end{array}$ & 10 minutes \\
\hline
\end{tabular}

\subsection{Hardness Stage}

In the hardness testing stage, the water sample is treated at the optimum parameters then the $\mathrm{CaCO} 3$ levels are determined in triple. The test results are presented in Table 3.

Table 3. Hardness test results with optimum parameters.

\begin{tabular}{|c|c|c|c|c|c|}
\hline \multirow{2}{*}{$\frac{\text { Parameter }}{\mathrm{CaCO}_{3}(\mathrm{mg} / \mathrm{L})}$} & \multirow{2}{*}{$\frac{\text { Initial water sample }}{348,45}$} & \multicolumn{3}{|c|}{ Treated water samples } & \multirow{2}{*}{$\begin{array}{r}\text { Average } \\
316,00\end{array}$} \\
\hline & & 318,15 & 318,15 & 310,58 & \\
\hline
\end{tabular}

Table 3. shows the value of hardness in treated water with optimum parameters. At this stage, there was a decrease in $\mathrm{CaCO}_{3}$ levels from $348.45 \mathrm{mg} / \mathrm{L}$ to $316.00 \mathrm{mg} / \mathrm{L}$ (average). This can be explained that in processing with optimum parameter conditions, the coagulation and flocculation processes take place perfectly so that it can coagulate the ions that cause hardness by forming large and precipitated flocks. To see the effect of Ipomoea batatas L. leaf extract as a flocculant in water treatment on decreasing hardness $\left(\mathrm{CaCO}_{3}\right)$ levels, a $\mathrm{CaCO}_{3}$ level was determined in water treated with coagulants compared to water treated with coagulants + Bio-flocculant Ipomoea batatas leaf extracts.

Table 4 shows the effectiveness of Ipomoea batatas L. leaf extract in reducing the hardness value $(\mathrm{CaCO} 3)$. The value of hardness is relatively smaller in water treated using Ipomoea batatas L. leaf extract compared to the hardness value in water treated without Ipomoea batatas L. leaf extract. Thus, it is reasonable to suspect that there are certain compounds in the Ipomoea batatas L. leaf extract that can bind ions -ion hardness. To prove it, we will do an FTIR Spectroscopy analysis.

Table 4. Test results for the effectiveness of Ipomoea batatas L. leaf extract as a flocculant.

\begin{tabular}{ccc}
\hline $\mathrm{CaCO}_{3}$ & $\mathrm{CaCO}_{3}$ & $\mathrm{CaCO}_{3}$ \\
(before) & (coagulants) & (coagulants + bio-flocculant) \\
\hline \multirow{3}{*}{348,45} & 303,00 & 318,15 \\
& 333,30 & 318,50 \\
& 318,50 & 310,58 \\
\hline
\end{tabular}


FTIR spectrum of leaves of Ipomoea batatas L. extract in Figure 3 above produces several absorption peaks of wave numbers including the wave number $3444 \mathrm{~cm}^{-1}$ is the absorption peak of the $\mathrm{OH}$ group, in the wavenumber region $2926 \mathrm{~cm}^{-1}$ is the absorption peak of the $\mathrm{CH}$ alkanes function group, the absorption peak $\mathrm{C}=\mathrm{C}$ alkenes functional groups obtained in the area of 1626 $\mathrm{cm}^{-1}$, in the region of $1581 \mathrm{~cm}^{-1}$ is the peak of absorption of the aromatic $\mathrm{C}=\mathrm{C}$ functional groups, the $\mathrm{CO}$ absorption peaks in this spectrum are in the region of $1076 \mathrm{~cm}^{-1}$, and nitro compounds are obtained in the area of $1342 \mathrm{~cm}^{-1}, 1317 \mathrm{~cm}^{-1}, 1512 \mathrm{~cm}^{-1}$, and $1523 \mathrm{~cm}^{-1}$.

Results of FTIR characterization analysis on the extract of Ipomoea batatas L. leaves, it can be concluded that the content contained therein consists of $\mathrm{OH}$ functional group bonds, $\mathrm{C}-\mathrm{H}$ alkanes, $\mathrm{C}=\mathrm{C}$ alkenes, $\mathrm{C}=\mathrm{C}$ aromatic rings, $\mathrm{C}-\mathrm{O}$, and nitro compounds. The existence of $\mathrm{OH}$ functional groups is thought to be a functional group capable of binding $\mathrm{Ca}^{2+}$ and $\mathrm{Mg}^{2+}$ ions, consequently, the water hardness becomes decreased.

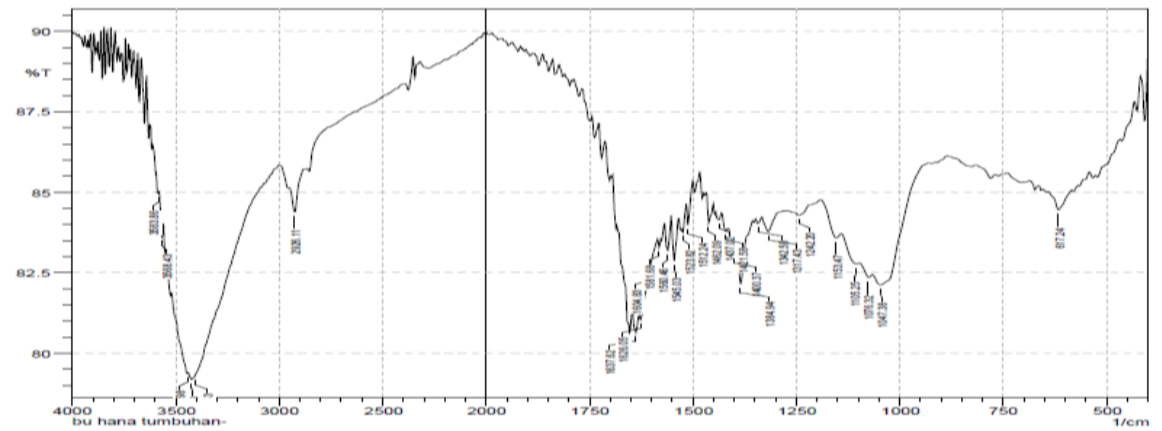

Fig. 3. FTIR Characterization Results of Ipomoea batatas L. Leaf Extract.

\section{Conclusion}

From the research results obtained optimum parameters of river water treatment in Padalarang Cimahi area using alum coagulant and Ipomoea batatas L. leaf flocculant extracts were $\mathrm{pH} 7.17$, coagulant concentration of $8 \mathrm{~mL}$, coagulant stirring speed of $200 \mathrm{rpm}$, stirring time of coagulant 7.5 minutes, flocculant concentration $3 \mathrm{~mL}$, the flocculant stirring speed of $30 \mathrm{rpm}$, the flocculant stirring time of 10 minutes succeeded in reducing $\mathrm{CaCO} 3$ levels in sample water from $348.45 \mathrm{mg} / \mathrm{L}$ to $316.00 \mathrm{mg} / \mathrm{L}$ or a decrease of about $9.31 \%$. This decrease shows that the extract of Ipomoea batatas $\mathrm{L}$. leaves has an $\mathrm{OH}$ group that is able to bind $\mathrm{Ca} 2+$ and $\mathrm{Mg} 2+$ ions so that Ipomoea batatas L can be used as a bio-flocculant in water treatment practicum activities at the University of Indonesia chemical research laboratory.

\section{References}

[1] Widayat, W.: Teknologi pengolahan air minum dari air baku yang mengandung kesadahan tinggi. Jurnal Air Indonesia, pp. 4(1) (2018)

[2] Koseki, M., Takahashi, M., Manki, R., Kitade, M., Okakura, Y., Imamura, M., \& Takahashi, H.: Evaluation of biological treatment for decreasing water hardness. Water Supply, 19(5), pp. 1541-1546 (2019) 
[3] Chaussemier, M., Pourmohtasham, E., Gelus, D., Pécoul, N., Perrot, H., Lédion, J., CheapCharpentier, H. \& Horner, O.: State of art of natural inhibitors of calcium carbonate scaling: a review article. Desalination 356, pp. 47-55 (2015)

[4] Sepehr, M. N., Yetilmezsoy, K., Marofi, S., Zarrabi, M., Ghaffari, H. R., Fingas, M. \& Foroughi, M.: Synthesis of nanosheet layered double hydroxides at lower $\mathrm{pH}$ : optimization of hardness and sulfate removal from drinking water samples. Journal of the Taiwan Institute of Chemical Engineers 45 (5), pp. 2786-2800 (2014)

[5] Sengupta, P.: Potential health impacts of hard water. International Journal of Preventive Medicine 4 (8), pp. 866-875 (2013)

[6] Joffres, M. R., Reed, D. M., \& Yano, K.: Relationship of magnesium intake and other dietary factors to blood pressure: the Honolulu heart study. The American journal of clinical nutrition, 45(2), pp. 469475 (1987)

[7] WHO 2011 Hardness in Drinking-Water. Background document for development of WHO Guidelines for Drinking-water Quality, WHO/HSE/WSH/10.01/10/Rev/1, WHO, Geneva, Switzerland. http://www.who.int/water_sanitation_health/dwq/chemicals/hardness.pdf (accessed on June 15, 2018).

[8] Rohana, H., \& Purwanti, S. T.: Uji Optimasi Ekstrak Daun Ipomoea Batatas L. Yang Digunakan Sebagai Flokulan Dalam Pengolahan Air Untuk Praktikum Pada Mata Kuliah Kimia Analisis Lingkungan. Jurnal Inovasi dan Pengelolaan Laboratorium, 1(1) (2019)

[9] Koncic, M. Z., Petlevski, R., \& Kalođera, Z.: Antioxidant Activity of Ipomoea batatas L. Lam. Leaf Grown in Continental Croatia and Its Effect on Glutathione Level in Glucose-Induced Oxidative Stress. International journal of food properties, 16(5), pp. 964-973 (2013)

[10] Luo, J. G., \& Kong, L. Y.: Study on flavonoids from leaf of Ipomoea batatas. Zhongguo Zhong yao za zhi= Zhongguo zhongyao zazhi= China journal of Chinese materia medica, 30(7), pp. 516-518 (2005)

[11] Ferreira, D., Barros, M., Oliveira, C. M., \& da Silva, R. J. B.: Quantification of the uncertainty of the visual detection of the end-point of a titration: Determination of total hardness in water. Microchemical Journal, 146, pp. 856-863 (2019)

[12] Musiam, S., Darmiani, S., \& Putra, A. M. P.: Analisis Kuantitatif Kesadahan Total Air Minum Isi Ulang Yang Dijual Di Wilayah Kayu Tangi Kota Banjarmasin. Jurnal Ilmiah Manuntung, 1(2), pp. 145148 (2017)

[13] Yudo, S., \& Said, N. I.: Pengolahan Air Limbah Industri Kecil Pelapisan Logam. Jurnal Air Indonesia, pp. 1(1) (2005)

[14] Wardani, R. S., Iswanto, B., \& Winarni, W.: Pengaruh Ph pada Proses Koagulasi dengan Koagulan Aluminum Sulfat dan Ferri Klorida. Jurnal Teknologi Lingkungan Universitas Trisakti, 5(2), pp. 40-45 (2009)

[15] Mujuadi, S.: Kemampuan Koagulan Poli Aluminium Chloride Untuk Menurunkan Warna Effluent Pengolahan Limbah PT. SIER. Laporan Tugas Akhir. Program Studi Teknik Lingkungan FTSP-ITS (1994) 